From the Department of Veterinary Virology and Immunology,

Royal Veterinary and Agricultural University, Copenhagen, Denmark and

Sysplan A/S, Holte, Denmark.

\title{
Studies on the Progression of Aleutian Disease in Mink
}

\author{
By Bent Aasted and Henrik Hauch
}

\begin{abstract}
Aasted, B. and H. Hauch: Studies on the progression of Aleutian disease in mink. Acta vet. scand. 1988, 29, 315-321. - One hundred ninetyfive male ADV-negative mink, including 79 pairs of brothers, were followed in their response to natural ADV-infection caused by mating with ADV-positive females and under epidemic conditions. Special attention was drawn to the development of progressive versus non-progressive Aleutian disease. This was done by plasmaelectrophoresis, detection of antibodies to ADV, and finally by macroscopical examination of mink organs at pelting time. We found that the progression of Aleutian disease presumably is under some genetic influence. We also found indication of differences in the response to ADV depending on how the infection was introduced. Mating to positive females (low virus concentration) resulted in significantly higher proportion of non-progressive responders than infection under epidemic conditions (high virus concentration).
\end{abstract}

Aleutian disease virus; parvo virus.

\section{Introduction}

Aleutian disease is a slowly progressing disease in mink. It is caused by persistent infection with Aleutian Disease Virus (ADV), a non-defective parvovirus (Bloom 1980). The disease is characterized by plasmacytosis, hypergammaglobulinemia and immune complex mediated glomerulonephritis and arteritis (for reviews see Porter et al. 1980, Lodmell \& Portis 1981 and Aasted 1985).

When non-Aleutian genotype mink from ADV infected farms were tested for antibody to ADV, an average of about one third of the animals were found to be ADV antibody negative (Aasted 1985).

By analysis of sera from 29 wild mink (obtained from a natural habitat) $55 \%$ of the mink were found to have antibodies against ADV (Ingram \& Cho 1974). It is likely that at least some of the serologically negative animals have been in contact with the virus but have developed a non-persistent infection. When studying this phenomenon in detail, Larsen \& Porter (1975) found that about one fourth of experimentally infected, non-Aleutian genotype mink develop a nonpersistent infection. The infected mink had only a transient increase of serum gammaglobulin and showed much lower specific antibody titres to ADV than did mink with persistent ADV. The mink with non-persistent infection were necropsied 500 days after infection and no lesions of AD were found. The non-persistency was found not to be genetically determined by the host and it was also found that no transplacentral ADV infection had occurred (Larsen \& Porter 1975). Serum samples from 33 mink with 
non-persistent infection taken 120 days after experimental infection were inoculated into Aleutian genotype indicator mink and only one serum sample (out of 33) was shown to transmit ADV.

In another study with 74 naturally infected mink An \& Ingram (1977) grouped the mink in two distinct groups: Those with low antibody titres and normal gammaglobulin values (39\%), and those with high antibody titres and hypergammaglobulinemia (61\%). They found that blood and organs from 3 mink which had had the non-progressive disease for at least 10 months contained ADV. The mesenteric lymph nodes and kidneys probably contained the highest concentration of virus, but virus was also found in blood, liver, and spleen. Only $50 \%$ of the indicator mink responded to the ADV from organs homogenates. This indicates that the amount of virus in the mink organs was small.

An et al. (1978) showed that stress did not induce progressive disease in mink with non-progressive AD. They also showed that mink with non-progressive AD could develop the progressive form after experimental challenge with the virus. Interestingly, it was shown that mink with non-progressive infection did transmit ADV horizontally as well as vertically by direct or indirect contact (An \& Ingram 1978).

In the present study we planned to follow 195 male ADV-negative mink, of which 79 were pairs in brothers, in their response to natural ADV infection caused by mating with ADV-positive females with special attention to the development of progressive versus non-progressive Aleutian disease.

\section{Materials and methods}

Mink

Two hundred and one ADV-negative males 1 year old "Wild type" mink (brown pure standard), were each mated with 6 to $7 \mathrm{ADV}$ positive females. The mink were kindly offered for experimentation by André Simon S.A., Priziac, France. They were housed in separate cages and fed a standard mink diet. The brother mink were placed in cages next to each other. Six mink escaped or died of unknown causes during the study. Included in the material were 195 males of which 158 comprised 79 pairs of brothers. The mink were all sacrificed at pelting time and macroscopically examined for pathological signs of AD.

\section{Plasma electrophoresis}

Blood was drawn in heparinized capillary tubes, and plasma isolated by centrifugation. Agarose electrophoresis (LSA agarose, Litex, Glostrup, Denmark) was carried out using the Tris/barbital buffer system (Svensen et al. 1978) adjusted to $\mathrm{pH}$ 7.5. The amido black staining procedure was used. The stained gels were scanned in a LKB 2202 ultroscan laser densitometer with automatic integration of the protein peaks.

The mink were classified as having progressive disease $(\mathrm{P})$ if the plasma concentration of gammaglobulin at the time of pelting was higher than $25 \%$ of the total plasma protein. They were classified as having non-progressive disease $(\mathrm{N})$ if the plasma concentration of gammaglobulin at the time of pelting was lower than $20 \%$ (except two mink with evident pathological signs of AD). Thirtythree mink with gammaglobulin concentrations from $20-24 \%$ were grouped as $12 \mathrm{P}$ and 21 $\mathrm{N}$ according to the gammaglobulin levels during the infection. Twenty-nine mink showed antibody to ADV for the first time in the blood sample taken approximately two months before pelting. This was considered too short a period to determine if the disease was progressive and these mink were therefore called unclassified (V). 


\section{Line electrophoresis}

Counter current line absorption immunoelectrophoresis (in short, line electrophoresis) was performed as described by Aasted et al. (1986). Line electrophoresis is approximately 20 times more sensitive than the counter current immunoelectrophoresis.
Counter current immunoelectrophoresis (CCIE) was performed as described by Cho \& Ingram (1972) except that $0.7 \%$ agarose gels (HSA agarose, Litex) were used. The antigen source was in vitro produced ADV-G (kindly supplied by the antigen laboratory, The Danish Fur Breeders Association, Glostrup, Denmark).

Table 1. Progression of Aleutian disease in a herd of mink. The numbers indicate percentage of gammaglobulin in relation to total plasma protein.

+ or - indicate presence or absence of antibody to Aleutian Disease Virus.

\begin{tabular}{|c|c|c|c|c|c|c|c|c|c|c|}
\hline \multirow{2}{*}{$\begin{array}{l}\text { Mink } \\
\text { No }\end{array}$} & \multicolumn{10}{|c|}{ Date of blood sample } \\
\hline & $4-2$ & $4-9$ & $4-17$ & 5-22 & 6-26 & $8-4$ & $10-16$ & $11-1$ & $12-9$ & Group \\
\hline 1.1 & - & - & - & - & - & +10 & + & +40 & +41 & $\mathrm{P}$ \\
\hline 1.3 & - & - & +24 & 0 & + & +29 & + & +20 & +22 & $\mathrm{~N}$ \\
\hline 1.4 & - & - & +14 & +29 & +16 & +14 & + & +9 & +15 & $\mathrm{~N}$ \\
\hline 1.5 & +11 & 0 & +22 & 0 & 0 & +35 & + & +29 & +29 & $\mathrm{P}$ \\
\hline 1.7 & - & - & - & - & - & - & + & +26 & +33 & $P$ \\
\hline 1.8 & - & - & - & - & - & - & + & +26 & +33 & $P$ \\
\hline 1.9 & - & - & - & +26 & + & +26 & + & +17 & +26 & $P$ \\
\hline 1.10 & - & - & +8 & +23 & +27 & +16 & + & +13 & +19 & $\mathrm{~N}$ \\
\hline 1.11 & - & - & + & +37 & +29 & +25 & + & +16 & +25 & $P$ \\
\hline 1.12 & +29 & 0 & +46 & 0 & 0 & +23 & + & +13 & +17 & $\mathrm{~N}$ \\
\hline 2.1 & - & - & + & +20 & + & +16 & + & +13 & +20 & $\mathrm{~N}$ \\
\hline 2.2 & - & - & 0 & + & 0 & +14 & + & +10 & +18 & $\mathrm{~N}$ \\
\hline 2.3 & - & - & - & - & +12 & +22 & + & +31 & +35 & $\mathrm{P}$ \\
\hline 2.4 & - & - & +29 & + & +17 & +11 & + & +11 & +26 & $\mathrm{P}$ \\
\hline 2.5 & - & - & - & - & - & - & + & +18 & +29 & V \\
\hline 2.6 & - & - & - & - & +21 & 0 & + & +18 & +22 & $\mathrm{~N}$ \\
\hline 2.7 & - & - & - & - & +25 & 0 & + & +21 & +31 & $\mathbf{P}$ \\
\hline 2.8 & - & - & - & - & - & - & + & +14 & +22 & V \\
\hline 2.10 & + & +24 & +27 & +44 & +45 & +28 & + & +17 & +24 & $\mathbf{P}$ \\
\hline 2.11 & - & - & - & - & +15 & +15 & + & +15 & +17 & $\mathrm{~N}$ \\
\hline 3.1 & - & - & +15 & +28 & +24 & +24 & + & +23 & +32 & $P$ \\
\hline 3.2 & - & - & - & - & - & - & + & +7 & +17 & V \\
\hline 3.3 & - & - & - & - & - & +21 & + & +17 & +23 & $\mathrm{~N}$ \\
\hline 3.4 & - & - & - & - & - & - & + & +26 & +32 & $\mathbf{P}$ \\
\hline
\end{tabular}

0 means insufficient amount of blood for analyses.

$\mathrm{N}$ means non-progressive course of infection.

$\mathrm{P}$ means progressive course ot infection.

$\mathrm{V}$ means unclassified.

The blood samples from October 16 were all completely haemolyzed, which made gammaglobulin quantitations impossible. 
Statistical analysis

Chi-square analysis and tests of indepence in a $2 \times 2$ contingency table were performed.

\section{Results}

Three blood samples were taken at weekly intervals starting 2 weeks after the last mating. Thereafter monthly blood samples were taken. The plasma samples were analyzed by line electrophoresis for presence of antibodies to ADV and by agarose electrophoresis for gammaglobulin quantification. The percentage of gammaglobulin in relation to total plasma protein was calculated. Table 1 shows a segment of the recordings.

To our surprise only $31 \mathrm{mink}(15.4 \%)$ had antibody to ADV two weeks after the last mating. These 31 mink we call primarily infected (i. e. during the mating procedure).

With time an AD epidemic developed on the farm resulting in $100 \%$ AD positive animals by October 16, 1986 as judged by line electrophoresis. The horizontal transmission pattern was very evident with the infection spreading from the primarily infected animals, see Table 1. The animals infected during the epidemic we call secondarily infected.

90 mink (46\%) were classified as having a non-progressive disease (N), $76(39 \%)$ as having a progressive disease $(\mathrm{P})$ and $29 \mathrm{mink}$ $(15 \%)$ could not be classified (V). Of the classified mink $54 \%(90 / 166)$ developed progressive $\mathrm{AD}$, see Table 2 a.

Interestingly, the N/P grouping of the 31 primarily infected mink showed that only 10 mink (32\%) were recorded as having progressive disease while $21(68 \%)$ were recorded as having non-progressive disease (see Table 2 b). Statistically this is significantly $(\mathrm{P}<0.05)$ different from the overall ration between $\mathrm{N}$ and $\mathrm{P}$ described above. This suggests that primarily infected mink (presumably exposed to a low virus burden
Table 2 a. Classification of 195 male mink by progression of ADV-infection.

\begin{tabular}{lrcc}
\hline Progression of AD & N & $\begin{array}{c}\text { \% of all } \\
\text { males }\end{array}$ & $\begin{array}{c}\text { \% of clas- } \\
\text { sified males }\end{array}$ \\
\hline Non-progressive & 90 & 46 & 54 \\
Progressive. & 76 & 39 & 46 \\
\cline { 2 - 3 } & 166 & 85 & 100 \\
All classified & 29 & 15 & \\
Unclassified & 195 & 100 & \\
All males & \multicolumn{2}{c}{100} \\
\hline
\end{tabular}

Table 2 b. Classification of 166 male mink by progression- and character of ADV-infection.

\begin{tabular}{lcccccc}
\hline & \multicolumn{5}{c}{ Character of ADV infection } \\
\cline { 2 - 7 } Progression of AD & Primary & \multicolumn{3}{c}{ Secondary } & Both ways \\
\hline \multirow{3}{*}{ Non-progressive } & 21 & 68 & 69 & 51 & 90 & 54 \\
Progressive & 10 & 32 & 66 & 49 & 76 & 46 \\
\cline { 2 - 7 } Total & 31 & 100 & 135 & 100 & 166 & 100 \\
\hline
\end{tabular}

Table $2 \mathrm{c}$. Classification of 55 pairs of brothers by progression of ADV infection.

\begin{tabular}{crrrr}
\hline & & \multicolumn{3}{c}{ Brother 1 } \\
\cline { 3 - 5 } & & $\mathrm{P}$ & $\mathrm{N}$ & Total \\
\cline { 3 - 5 } Brother & $\mathrm{P}$ & 19 & 8 & 27 \\
2 & $\mathrm{~N}$ & 9 & 19 & 28 \\
\cline { 3 - 5 } & Total & 28 & 27 & 55 \\
\hline
\end{tabular}

Table $2 \mathrm{~d}$. Classification of 59 pairs of non-related neighbour mink by progression of ADV infection.

\begin{tabular}{lrrrr}
\hline & & \multicolumn{3}{c}{ Neighbour I } \\
\cline { 3 - 5 } & & $\mathrm{P}$ & $\mathrm{N}$ & Total \\
\cline { 3 - 5 } Neighbour & $\mathrm{P}$ & 11 & 16 & 27 \\
2 & $\mathrm{~N}$ & 11 & 21 & 32 \\
\cline { 3 - 5 } & Total & 22 & 37 & 59 \\
\hline
\end{tabular}


during mating because only $15 \%$ of the mink were infected primarily) develop a lower incidence of progressive disease than the secondarily infected mink.

When the P, N or V classification was considered for the 79 pairs of brothers we found that 55 pairs had a $\mathrm{P}$ or $\mathrm{N}$ classification. $\mathrm{A}$ test of independence in a $2 \times 2$ contingency table was performed on this material (Table $2 \mathrm{c}$ ). The probability of independence is less than 0.003 . Moreover, the association derives from an excess of pairs where both brothers are $\mathrm{P}$ (19 pairs) or both $\mathrm{N}$ (likewise 19 pairs). These concomitant phenomena suggest some genetic influence as discussed further in the following.

The brothers were during the investigation housed in cages next to each other. In order to test for the possibility of bias under these conditions, a similar comparison was made on non-related neighbour mink. These results are presented in Table $2 \mathrm{~d}$. The statistical evaluation of these data gave a very high probability of independence $(p>0.3)$.

\section{Discussion}

The fact that only $15.4 \%$ of the mink were infected during mating indicates that the virus concentration transmitted during mating is low. This should be seen in the light of the rather high percentage of non-progressive AD found in this study ( $54 \%$ ). A mink farmer will endeavour to select apparently healthy mink for the breeding stock and in this way favours mink with non-progressive infection (or no infection). Such mink are known to contain very low virus concentration (An \& Ingram 1978), if any (Larsen \& Porter 1975).

When we studied the N/P-grouping (nonprogressive versus progressive) of the 31 primarily infected mink we found a surprising (and significant) proportion of the mink with non-progressive infection.
When we combine these two observations we tentatively conclude (although evidence is indirect only in the present study) that a low virus burden tends to give a non-progressive infection. A direct experimental study to investigate this point is ongoing.

When we analyzed the N/P status of 55 pairs of brothers in relation to the $\mathrm{N}$ and $\mathrm{P}$ frequencies in the total material, we concluded that some genetic component involved in the progression of the disease is very likely ( $\mathrm{p}<0.003$ ).

There is however a bias caused by the fact that in 31 of the cases one brother was primarily infected while the other brother was secondarily infected. With the different N/P ratios described above, this causes a downward bias of the level of significance, and thus a lower probability to detect a genetic component.

Another potential bias caused by the brothers always being neighbours was actually tested in the study and found not to influence the results.

If the progression of Aleutian disease is under some genetic influence it should be possible to keep the percentage of ADV-infected mink which suffer from the progressive disease on a low level in mink farms by selecting mink with non-progressive disease, if any, for breeding. Several years of studies will be needed to examine this hypothesis. Experiments have been started.

During the 8 months test period we only found one mink with non-persistent infection which reverted from a positive counter current immuno-electrophoresis reaction to a negative. Two other mink with non-persistent infection reverted from a positive reaction to a doubtful positive reaction in the CCIE. As mentioned in the introduction, this is what would be expected and chances are that if we had prolonged the test period 
we would have found more examples of this phenomenon.

The ratio between non-progressive versus progressive disease was somewhat higher in our study (54\%) than in the study of Larsen \& Porter (1975) and An \& Ingram (1977). We believe there are two reasons for this; the first being that the sera with gammaglobulin concentration from $20-24 \%$ could be grouped as $\mathrm{N}$ and $\mathrm{P}$ according to individual judgement while the two other studies mentioned grouped all mink with gammaglobulin concentrations above $20 \%$ as progressive. The other explanation is that the mink we studied were "Wild type" mink. Mink farmers regard these mink as being very healthy mink and many mink farmers indeed regard "Wild" mink as being more resistant to ADV than other mink types.

\section{Acknowledgements}

Knud Christensen, Department of Animal Genetics, Royal Veterinary and Agricultural University, Copenhagen, Denmark, was most helpful in contributing his expertise in genetics to the planning and evaluation phases of this research which we gratefully acknowledge. However, responsibility for any error or omission rests solely with the authors.

The technical assistance of Ms. Else Bang Larsen and Ms. Anne Friis Petersen is greatly acknowledged. This work was supported by grants from the Danish Veterinary and Agricultural Research Council, the Danish Fur Breeders Association Research Foundation, André Simon S. A., and Sysplan A/S.

\section{References}

Aasted B: Aleutian disease of mink. Virology and immunology. Acta path. microbiol. immunol. scand. Sect. C 1985, suppl. 287, vol. 93.

Aasted B, Alexandersen S, Cohn A, Hansen M: Counter current line absorption immunoelectrophoresis in an alternative diagnostic screening test to counter current immunoelectrophoresis in Aleutian disease (AD) eradication programs. Acta vet. scand. 1986, 27, 410-420.
An SH, Ingram DG: Detection of inapparent Aleutian disease virus infection in mink. Amer. J. vet. Res. 1977, 38, 1619-1624.

An SH, Ingram DG: Transmission of Aleutian disease from mink with inapparent infections. Amer. J. vet. Res. 1978, 39, 309-313.

An SH, de Pauli FJ, Wright P, Ingram DG: Characteristics of inapparent Aleutian disease virus infection in mink. Res. Vet. Sci. 1978, 24, 200-204.

Bloom, ME, Race RE, Wolfinbarger JB: Characterization of Aleutian disease virus as a parvovirus. J. Virol. 1980, 35, 836-843.

Cho HJ, Ingram DG: Antigen and antibody in Aleutian disease in mink. I. Precipitation reaction by agar-gel electrophoresis. J. Immunol. 1972, 108, 555-557.

Ingram DG, Cho HJ: Aleutian disease in mink: Virology, immunology and pathogenesis. Rheumatology 1974, 1, 74-91.

Larsen AE, Porter DD: Pathogenesis of Aleutian disease of mink: Identification of nonpersistent infections. Infect. Immun. 1975, 11, 9294.

Lodmell DL, Portis $J L$ : Immunologic and genetic aspects of Aleutian disease. In: Immunological defects in laboratory animals 2, (eds. Gerschwin and merchant) Plenum press, NY \& London 1981, pp 39-75.

Porter DD, Larsen AE, Porter HG: Aleutian disease of mink. Adv. Immunol. 1980, 29, 261286.

Svensen PJ, Weeke B, Johansson B-G: Chemicals, solutions, equipment and general procedures. Scand. J. Immunol. 1983, Suppl. 10, vol. 17, pp 3-20.

\section{Sammendrag}

Undersøgelse af udviklingen af plasmacytose

hos mink.

Ethundredeogfemoghalvfems plasmacytose-negative hanmink, inclusive 79 broderpar, blev fulgt med henblik på deres reaktion på naturlig plasmacytose-infektion forårsaget dels ved parring med plasmacytose-positive hunner og dels under epidemiske omstændigheder. Særlig opmærksomhed blev rettet mod udviklingen af progressiv kontra ikke-progressiv plasmacytose. Dette undersøgtes 
ved plasmaelektroforese, sporing af plasmacytoseantistof og slutteligt ved makroskopisk undersøgelse af minkorganer. Vi fandt, at udviklingen af plasmacytose sandsynligvis er genetisk influeret. Vi fandt også indikation for, at mink reagerer forskelligt på infektion med plasmacytosevirus og at forskellen er afhængig af infektionsmåden. Parring med positive hunner (lav viruskoncentration) gav signifikant højere ratio af ikke-progressive forløb af plasmacytose end infektion under epidemiske forhold (høj viruskoncentration).

(Received October 9, 1987; accepted January 4, 1988).

Reprints may be requested from: B. Aasted, Department of Veterinary Virology and Immunology, Royal Veterinary and Agricultural University, Bülowsvej 13, DK-1870 Frederiksberg C, Denmark. 
